\title{
AKTIVASI EKSPRESI PROTEIN DAN GEN AQUAPORIN 3 (AQP 3 ) SEBAGAI TARGET PENGOBATAN HIDRASI KULIT
}

\author{
Linda Yulianti Wijayadi
}

Fakultas Kedokteran, Universitas Tarumanagara

Email:lindaj@fk.untar.ac.id

\begin{abstract}
ABSTRAK
Kelompok protein Aquaporins (AQPs) dikenal sebagai saluran air dan gliserol untuk memfasilitasi transportasi air dan gliserol yang melintasi membran sel dan juga memiliki peranan dalam pemeliharaan kelembaban lapisan epidermis. Aquaporin $3\left(\mathrm{AQP}_{3}\right)$ adalah bagian dari aquaglyceroporin dan banyak terdapat pada membran plasma keratin pada lapisan epidermis kulit. Ekspresi $\mathrm{AQP}_{3}$ tampak dalam sel keratinosit dan fibroblas kulit. $\mathrm{AQP}_{3}$ terlihat pada lapisan basal dari epidermis kulit, spinosum dan jaringan fibroblast kulit dibagian dermis kulit. Tanda terjadinya penuaan kulit adalah keringnya kulit, peningkatkan kerapuhan kulit, penurunan elastisitas dan penyembuhan luka yang tertunda. $\mathrm{AQP}_{3}$ adalah protein utama yang mempengaruhi hidrasi kulit dan menurun pada penuaan kulit. $\mathrm{AQP}_{3}$ menjadi protein kunci untuk target pengobatan masa depan terhadap penuaan kulit (kulit kering), sehingga mulai banyak dibuat pelembab yang dapat mengekspresikan protein $\mathrm{AQP}_{3}$
\end{abstract}

Kata kunci: Aquaporin 3, Hidrasi, Hidrasi Kulit, Aquaglyseroporin, Keratinosit, Fibroblast, Penuaan, Penuaan Kulit.

\section{ABSTRACT}

The protein family of Aquaporins (AQPS) known as water and glycerol channels to facilitate the transport of water and glycerol across cell membrane and also have the role in epidermal water maintenance. Aquaporins-3 (AQP $\left.P_{3}\right)$ is a member of aquaglyceroporin and the must abundant $A Q P_{3}$ present in the skin, in plasma membrane of epidermal cells. $\mathrm{AQP}_{3}$ showed expression in skin keratinocyte in basal layer of epidermis and spinosum, and in fibroblast skin dermis. A feature of skin aging is dry skin, increase skin fragility, decrease elasity and delayed wound healing. $A Q P_{3}$ is a major protein implicated in skin hydration and decrease with skin aging therefor AQP $P_{3}$ appears to be a key protein as a target and potential target for drug development for the future treatment of skin aging (dry skin), as a novel moisturizer.

Keywords: Aquaporin 3, Hydration, Skin Hydration, Keratinocyte, Fibroblast, Aging, Skin Aging.

\section{PENDAHULUAN}

Epidermis merupakan lapisan terluar dari kulit manusia yang berfungsi sebagai barrier efektif untuk mengontrol pertukaran air dan perlindungan terhadap dehidrasi, yang sangat penting untuk homeostasis pada fungsi fisiologis kulit. Epidermis kulit juga berfungsi sebagai lapisan pelindung terhadap organisme berbahaya seperti virus, bakteri, jamur, dan partikel antigenik lainnya. Stratum korneum (SK) sebagai pelindung kulit berasal dari epidermal yang berdiferensiasi berupa sel-sel keratinosit pipih (korneosit) dan merupakan sel mati. $(1,2)$

Kadar air (hidrasi) SK memiliki pengaruh besar pada penampilan dan sifat fisik kulit. Faktorfaktor yang mengontrol kadar air SK, antara lain yaitu kelembaban eksternal, komposisi lipid, urea, protein, dan konsentrasi osmolitas penahan air atau faktor pelembab alami. $(1,3)$

Pada penuaan kulit dan beberapa penyakit kulit hidrasi SK berkurang, termasuk dermatitis atopik, eksim, psoriasis, xerosis senilis, dan iktiosis herediter. $(1,2,4)$ Penuaan kulit adalah hasil proses yang kompleks dari gabungan penuaan kronologis karena faktor genetik (penuaan intrinsik) dan modifikasi pengaruh yang dihasilkan dari faktor eksternal (penuaan ekstrinsik). Penuaan kulit menyebabkan berbagai modifikasi dalam sel dan jaringan pada dermal dan epidermal yang 
berperan dalam sifat fisik dan mekanik kulit $(5,6)$ Pada kulit yang menua terjadi penurunan kadar air dan fungsi sawar kulit termasuk xerosis kutis, akibat peningkatan deskuamasi kerapuhan kulit dan penyembuhan luka yang tertunda. $(1,5,7)$

Gambaran klinis kulit menua adalah menjadi kering, kusam, permukaan kasar, kendur, timbul garis dan kerut. Faktor penting lain yang berperan dalam hidrasi kulit adalah adanya aquaglyceroporins $(2,4,7)$. Aquaporins (AQPs) adalah sekelompok kecil protein, hidrofobik, protein membran integral yang berfungsi terutama sebagai pori-pori air selektif, memfasilitasi transportasi air yang secara osmotik melintasi membran plasma sel. Setidaknya ada 13 AQPs mamalia $\left(\mathrm{AQP}_{0}-\mathrm{AQP}_{12}\right)$, yang telah dibagi menjadi dua kelompok berdasarkan permeabilitas mereka. AQPs 1, 2, 4, 5, dan 8 berfungsi sebagai transporter air-selektif; AQPs 3, 7, 9, dan 10, disebut "aquaglyceroporins", berfungsi sebagai transporter air serta gliserol dan mungkin zat terlarut kecil lainnya. Aquaglyceroporins permeabel terhadap air serta zat terlarut kecil, seperti gliserol dan urea. (8)

Beberapa penelitian menunjukkan bahwa AQP merupakan target obat yang potensial, tidak hanya untuk reagen diuretic retensi air patologis, tetapi juga menargetkan untuk terapi novel edema otak, penyakit radang, glaukoma, obesitas dan kanker. Namun, modulator poten AQP untuk aplikasi in vivo masih harus diteliti. (9)

\section{METODE PENELITIAN}

\section{EKSPRESI PROTEIN AQP3}

$\mathrm{AQP}_{3}$ terekspresi di epidermis kulit manusia pada membran plasma keratinosit stratum basale dan stratum spinosum. $\mathrm{AQP}_{3}$ tidak terdeteksi dalam stratum granulosum dan stratum korneum (lapisan superfisial epidermis). (2,4,7,8,10)

Gen $\mathrm{AQP}_{3}$ dan ekspresi protein $\mathrm{AQP}_{3}$ menurun pada kulit usia lanjut yang terpapar sinar matahari (11).

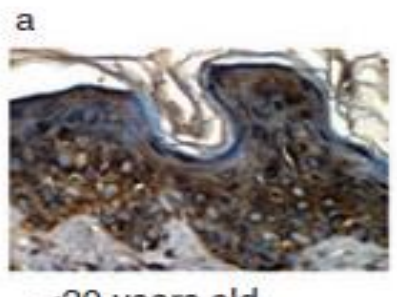

$<20$ years old

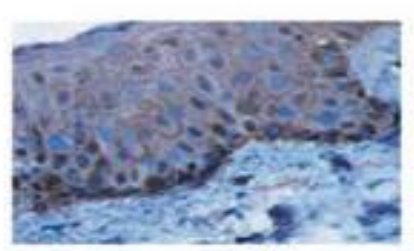

$30-45$ years old b

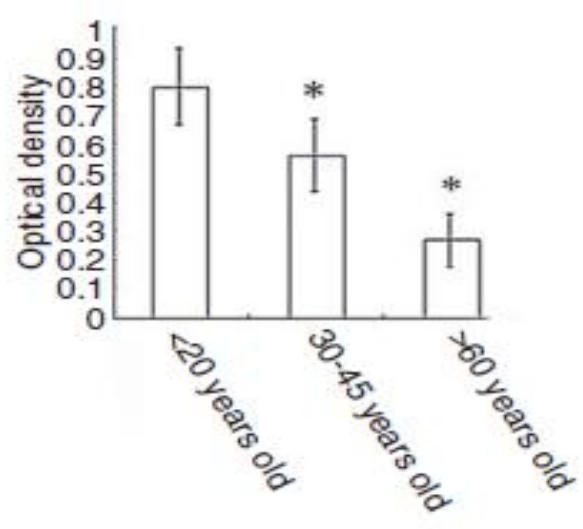

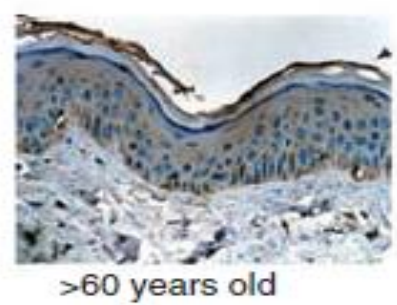

Gambar 1. Ekspresi aquaporin $3\left(\mathrm{AQP}_{3}\right)$ pada kulit manusia normal. (a) imunohistokimia $\mathrm{AQP}_{3}$ berlabel (coklat) pada epidermis untuk setiap kelompok (¥400). (b) Grafik meringkas data yang disajikan dalam (a). $\mathrm{n}=20$ kelompok umur < 20 tahun: 0,80 - 0,13; Kelompok umur 30-45 tahun : 0,56 - 0,12; Kelompok > 60 tahun: 0,27 0,09. * Signifikan secara statistik sehubungan dengan kelompok lain pada $\mathrm{P}<0,05$. (11)

\section{EKSPRESI AQP3 PADA KERATINOSIT KULIT MANUSIA}

Ekspresi $\mathrm{AQP}_{3}$ ini dinyatakan dalam membran keratinosit epidermis dan sitoplasma keratinosit, tampak sangat banyak dalam kelompok umur $<20$ tahun (Gbr.1). RT-PCR, imunositokimia dan 
analisis western blot menunjukkan bahwa $\mathrm{AQP}_{3}$ mRNA dan protein secara signifikan lebih rendah pada kelompok umur $>60$ tahun daripada usia 30-45 tahun $(\mathrm{P}<0,05)$ dan kelompok umur $<20$ tahun dalam keratinosit epidermis kulit manusia yang normal (NHEK) $(\mathrm{P}<0,05) . \mathrm{AQP}_{3}$ mRNA dan protein di NHEK berasal dari kelompok umur 30-45 tahun secara signifikan lebih rendah daripada yang berasal dari kelompok umur < 20 tahun $(\mathrm{n}=6)(\mathrm{Gambar} 2)$. (11) $\mathrm{AQP}_{3}$ juga terekspresi pada sel fibroblast kulit manusia. $(11,12)$
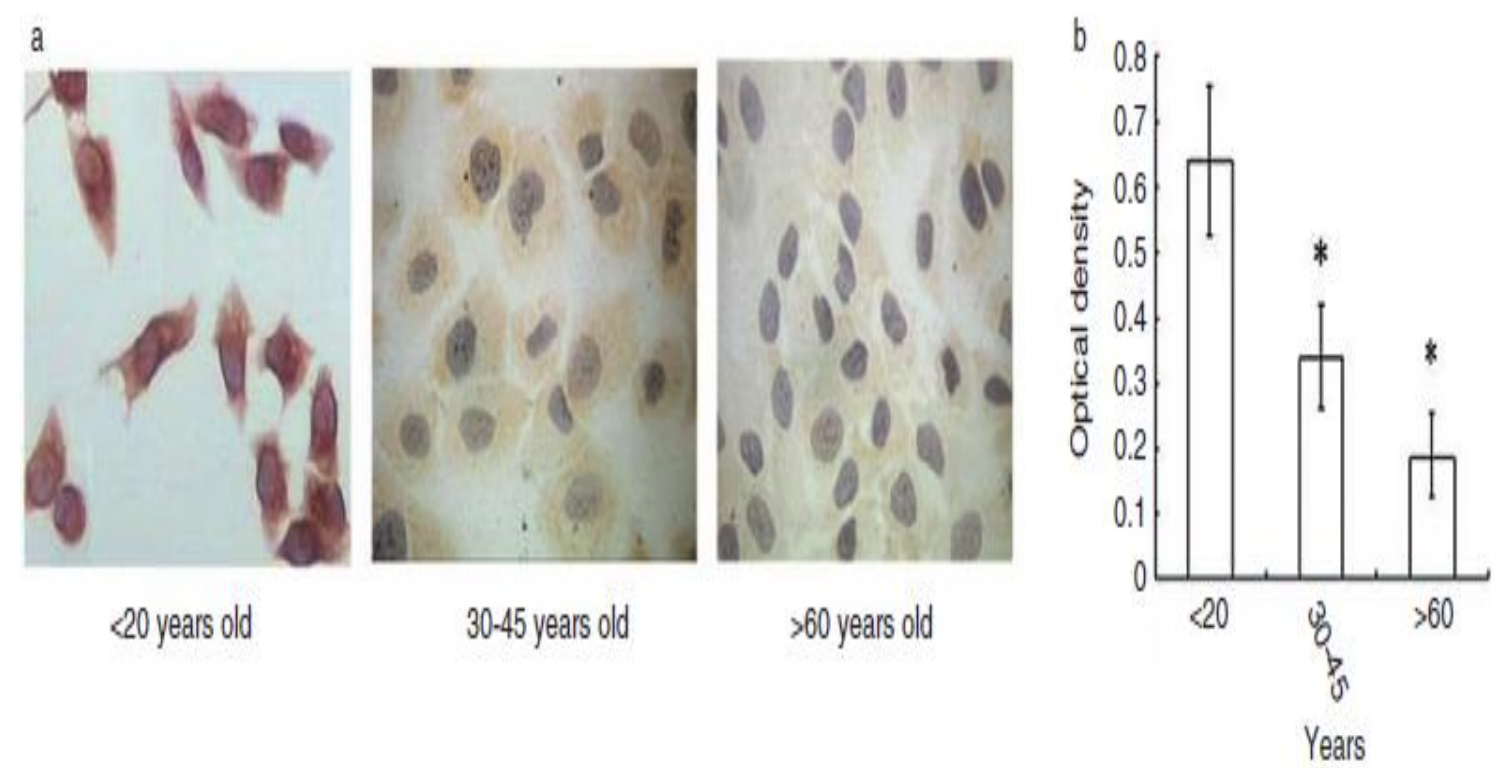

Gambar 2. Ekspresi aquaporin-3 ( $\left.\mathrm{AQP}_{3}\right)$ dalam keratinosit. (a) immunocytochemistry $\mathrm{AQP}_{3}$ berlabel (coklat) normal keratinosit epidermal manusia (NHEK) di masing-masing kelompok (¥ 400). (b) Grafik meringkas data yang disajikan dalam (a). $\mathrm{n}=6$ kelompok umur < 20 tahun: 0,64 - 0,12; Kelompok umur 30-45 tahun: 0,34 - 0,08; Kelompok umur > 60 tahun: $0,18-0,06$. ${ }^{*}$ Signifikan secara statistik sehubungan dengan kelompok lain pada $\mathrm{P}<$ 0,05. (11)

\section{EKSPRESI AQP3 PADA FIBROBLAS KULIT MANUSIA}

$\mathrm{AQP}_{3}$ diekspresikan dalam membran sitoplasma fibroblas, terekspresi dalam jumlah yang cukup banyak dalam kelompok umur $<20$ tahun dan usia 30-45-tahun (Gbr.1). Hasil RT-PCR, imunositokimia dan analisis western blot menunjukkan bahwa $\mathrm{AQP}_{3} \mathrm{mRNA}$ dan protein dalam fibroblas pada kelompok umur $>60$ tahun menurun secara signifikan $(\mathrm{P}<0,05)$. Tidak ada perbedaan yang signifikan antara kelompok umur $<20$ tahun dan kelompok umur 30-45 tahun (n $=6)(\mathrm{P}>0,05)$ (gambar 3). (11)

Penelitian Cao dkk membuktikan bahwa AQP3, juga terekspresi pada kultur sel fibroblast kulit manusia, yang pada proses penyembuhan luka normal dengan adanya EGF (Epidermal Growth Factor), mengontrol migrasi sel fibroblast dan juga menginduksi ekspresi AQP3 dimana proses ini (EGFR-Mediated expression) sangat tergantung pada dosis dan waktu. (12) 
a

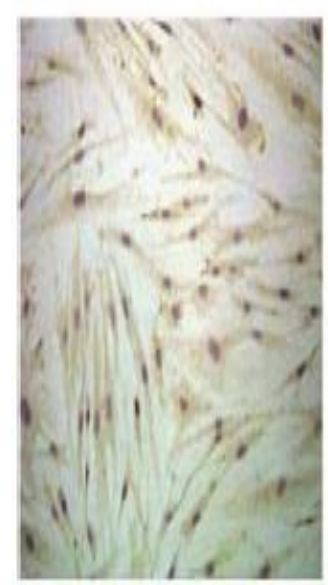

<20 years old

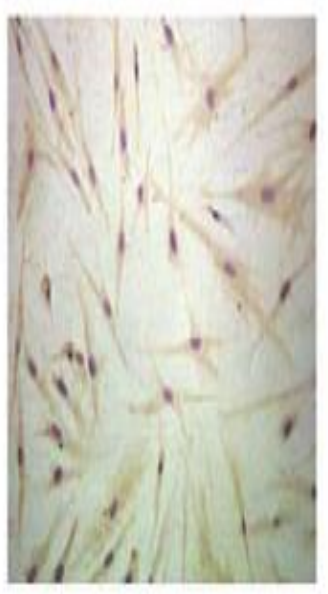

$30-45$ years old

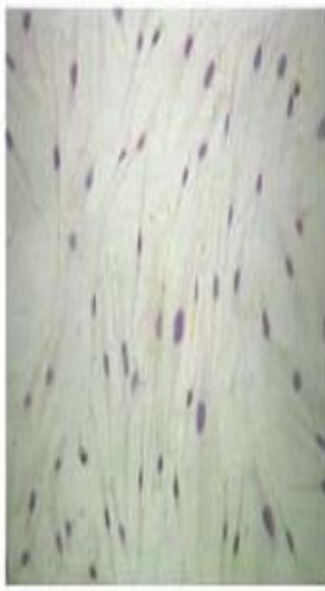

$>60$ years old

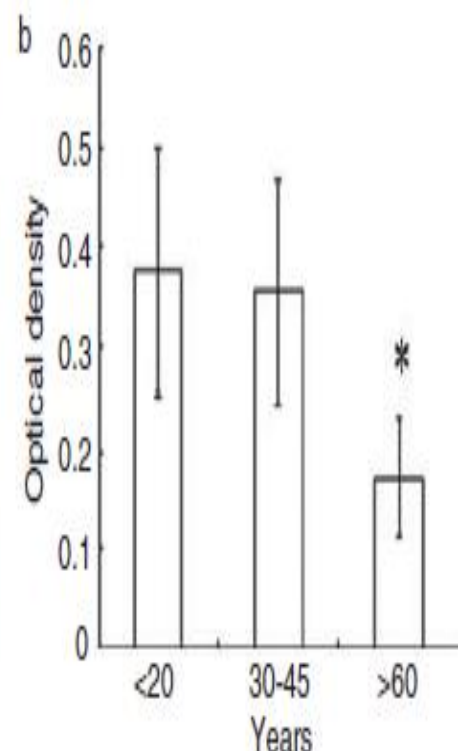

Gambar 3. Ekspresi aquaporin-3 ( $\left.\mathrm{AQP}_{3}\right)$ dalam fibroblas. (a) immunocytochemistry $\mathrm{AQP}_{3}$ berlabel (coklat) fibroblas dalam setiap kelompok (¥ 200). (b) Grafik meringkas data yang disajikan dalam (a). $n=6$ kelompok umur < 20 tahun: 0,38_0,12; Kelompok umur 30-45 tahun: 0,35_0,11; Kelompok umur > 60 tahun: 0.17 - 0.06. * Signifikan secara statistik sehubungan dengan kelompok lain pada $\mathrm{P}<0,05$. Hasil percobaan ditunjukkan untuk sel yang dipilih tunggal merupakan perwakilan dari hampir semua populasi sel diuji. (10)

$\mathrm{AQP}_{3}$ sebagai saluran transportasi air dan gliserol (water and glyserol channel). Pada tikus yang kekurangan $\mathrm{AQP}_{3}$ menunjukkan kekeringan pada kulit, akibat penurunan kadar gliserol dan penurunan kapasitas menahan air, pemulihan sawar kulit dan penyembuhan luka yang terlambat. (13)
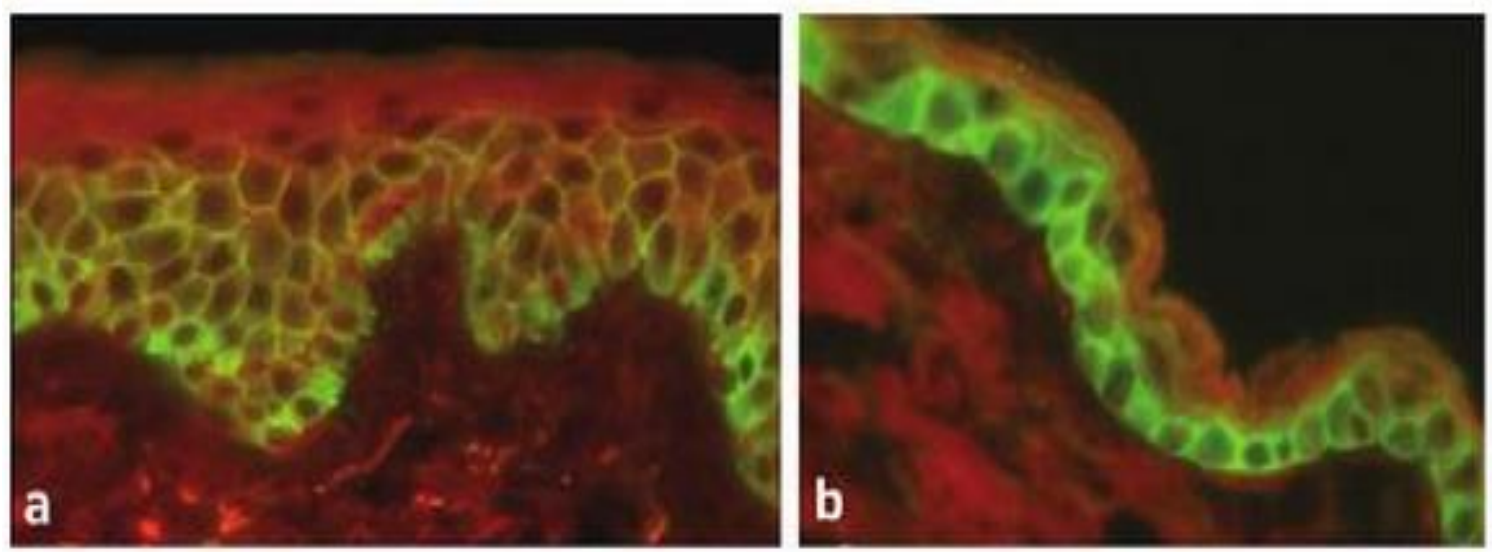

Gambar

4. Immunolocalization dari $\mathrm{AQP}_{3}$ dengan imunofluoresensi langsung (hijau) pada epidermis manusia (a) dan tikus

(b). Dalam epidermis manusia, $\mathrm{AQP}_{3}$ ditemukan dalam stratum basale dan stratum spinosum. Dalam epidermis tikus, $\mathrm{AQP}_{3}$ hanya terdeteksi pada stratum basale. Sedikit atau tidak ada pewarnaan lapisan granulosum atau stratum korneum terdeteksi baik spesies. Diadaptasi dari Boury-Jamot et al. (2006)

Penelitian Mirza dkk, menemukan adanya peningkatan ekspresi $\mathrm{AQP}_{3}$ pada epidermis dari

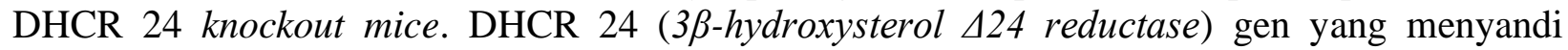
enzim katalisa perubahan desmosterol menjadi icolestrol. Penelitian Mirza dkk ini menunjukkan bahwa peningkatan $\mathrm{AQP}_{3}$ itu menghasilkan retensi air di epidermis menghasilkan fenotipe kulit DHCR 24 tikus yang bebas keriput dan bercahaya. (14) 
$\mathrm{AQP}_{3}$ diekspresikan pada lapisan basal keratinosit pada kulit normal, fungsinya terutama untuk memungkinkan gliserol pindah ke lapisan atas dari epidermis dan SK (5). Studi pada tikus yang kekurangan $\mathrm{AQP}_{3}$ menunjukkan kulitnya kering dengan berkurangnya hidrasi $\mathrm{SK}$, penurunan elastisitas, dan gangguan biosintesis, hal ini menunjukkan pentingnya $\mathrm{AQP}_{3}$ dalam fisiologi kulit dan menyediakan dasar ilmiah yang rasional untuk pengujian gliserol terhadap kosmetik dan persiapan kulit untuk tindakan medis. $(13,17,18)$

\section{HASIL DAN PEMBAHASAN}

\section{BEBERAPA PENELITIAN EKSPRESI PROTEIN AQP3 PADA KULIT MANUSIA}

\section{A. Ekstrak Ceratonia siligina sebagai bahan aktif penginduksi AQP3}

Salah satu fungsi utama kulit adalah untuk melindungi organisme terhadap ancaman lingkungan, seperti stres lingkungan. Aquaporin-3 ( $\left.\mathrm{AQP}_{3}\right)$ memfasilitasi air dan gliserol melintasi membran sel dan mengatur keseimbangan osmotik dalam situasi stress yang berbeda-beda. Mekanisme ini menjadi sangat penting untuk perlawanan organisme yang berbeda terhadap stres dingin. Untuk menguji pengaruh stres dingin dan osmotik terhadap ekspresi $\mathrm{AQP}_{3}$ dalam keratinosit kulit manusia normal, dikembangkan bahan aktif baru untuk merangsang aquaporins di kulit dan menunjukkan pemulihan sebagian ekspresi $\mathrm{AQP}_{3}$ dalam keratinosit transfected dengan $\mathrm{AQP}_{3}$ siRNA. Bahan aktif yang berperan sebagai $\mathrm{AQP}_{3}$ inducer adalah ekstrak ceratoniasiliqua (biji carab) yang kaya asam amino dan peptide. Selain itu, dilakukan pengujian pengaruh stres dingin pada morfologi sel keratinosit dan dampak kerusakan yang ditimbulkan akibat paparan dingin pada kulit yang diterapi dengan $\mathrm{AQP}_{3}$ dibandingkan dengan yang tidak. Hasilnya menunjukkan sel keratinosit yang diterapi dengan bahan induksi aktif $\mathrm{AQP}_{3}$, yaitu ekstrak Ceratonia siligina lebih tahan terhadap pengaruh stres dingin dan terjadi peningkatan ekspresi $\mathrm{AQP}_{3}$ pada keratinosit. (15)

B. Asam retinoat meningkatkan ekspresi $\mathrm{AQP}_{3}$ pada kulit normal manusia

Penelitian ini melihat pengaruh All Trans Retinoic Acid (ATRA) pada ekspresi dan fungsi $\mathrm{AQP}_{3}$ baik in vitro dan ex vivo. Pengobatan ATRA memicu akumulasi cepat ekspresi $\mathrm{AQP}_{3}$ dalam keratinosit epidermal manusia. Peningkatan ini masih diamati 24 jam setelah aplikasi ATRA. Induksi gen $\mathrm{AQP}_{3}$ disertai dengan peningkatan immunoreactivity. Dengan menggunakan agonis selektif, penelitian menunjukkan bahwa efek dari ATRA terutama dimediasi oleh retinoat subtipe reseptor asam gamma (RARgamma). Inkubasi NHEK (Normal Human Epidermal Keratinocyte) dengan ATRA selama 24, 48, dan 72 jam merangsang masuknya gliserol, menunjukkan bahwa peningkatan gen $\mathrm{AQP}_{3}$ dan ekspresi protein diikuti oleh peningkatan aktivitas biologis. Aplikasi topikal dari ATRA selama 24 jam pada kulit eksplan menginduksi ekspresi signifikan dari $\mathrm{AQP}_{3}$ di epidermal kulit dan timbul immunoreactivity yang kuat di lapisan basal epidermis. Secara kolektif, hasil ini menunjukkan bahwa peningkatan ekspresi $\mathrm{AQP}_{3}$ dan meningkatkan aktivitas biologis pada kulit manusia.(16) Pemaparan lapisan epidermis kulit manusia (kulit eksplan) dengan 0,05\% ATRA selama 3 jam tidak memprovokasi variasi hasil ekspresi, terlihat dalam intensitas pewarnaan dan tidak memodifikasi $\mathrm{AQP}_{3}$ lokalisasi di epidermis (Gambar 5e). Demikian pula, ketika ATRA dipaparkan selama 24 jam, tidak ada modifikasi immunoreactivity $\mathrm{AQP}_{3}$ yang dapat diamati (Gambar 5g). Sebaliknya, ketika kulit eksplan dipaparkan dengan 0,05\% ATRA selama 48 jam, peningkatan intensitas pewarnaan divisualisasikan pada semua lapisan epidermal. Selain itu, lapisan basal epidermis memamerkan label intraseluler yang luar biasa, menunjukkan bahwa $\mathrm{AQP}_{3}$ yang baru disintesis dapat terakumulasi dalam sitoplasma sel basal (Gambar 5i). (16,19) 

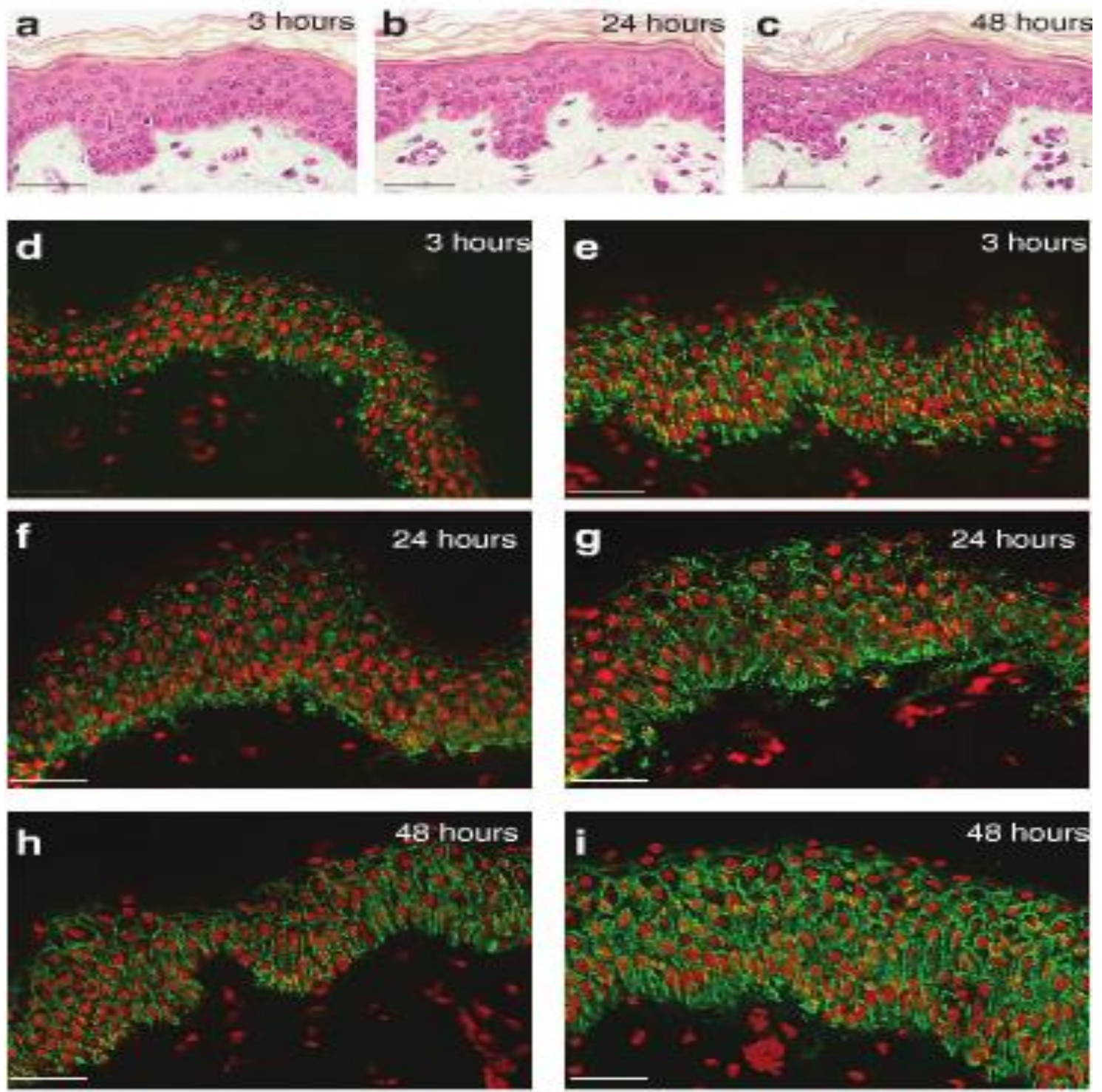

Gambar 5. Aplikasi topikal dari ATRA mengandung emulsi merangsang akumulasi dari $\mathrm{AQP}_{3}$ immunoreactivity dalam eksplan kulit manusia. Untuk memvisualisasikan integritas jaringan, bagian kulit yang tidak diobati yang bernoda menggunakan Masson Trichrome (a-c). Eksplan kulit diobati dengan $5 \mathrm{ml}$ plasebo (d, f, h) atau ATRA yang mengandung emulsi (e, g, i) selama 3 jam (d, e), 24 jam (f, g), dan 48 jam (h , i). Bagian kulit yang immunostained oleh kelinci antiserum ditujukan terhadap AQP3 (d-i). Bar 1/4 50 mm.

\section{Semua All trans retinoic acid (ATRA) menghambat penurunan permeabilitas air dalam keratinosit kulit manusia akibat radiasi sinar UV}

Salah satu karakteristik utama dari faktor ekstrinsik penuaan kulit disebabkan oleh radiasi sinar ultraviolet (UV) adalah dehidrasi kulit. Pergerakan air melintasi membran plasma terjadi secara difusi melalui lipid bilayer dan melalui aquaporins (AQPs). UV menginduksi down-regulasi $\mathrm{AQP}_{3}$ dalam keratinosit kulit manusia. ATRA menginduksi ekspresi AQP3, melemahkan efek UV down-regulation $\mathrm{AQP}_{3}$ dan permeabilitas air. Efek UV yang menghasilkan $\mathrm{AQP}_{3}$ down-regulation berperan dalam mengurangi permeabilitas air, penurunan migrasi sel, dan penyembuhan luka yang tertunda, dilemahkan oleh terapi ATRA. ATRA melindungi UV induced down-regulation $\mathrm{AQP}_{3}$ dan penurunan permeabilitas air, pengurangan migrasi sel dan penundaan pada in vitro penyembuhan luka melalui transaktivasi EGFR (Epidermal Growth Factor Receptor) dan inhibisi pada ROS (Reactive Oxygen Species) dimediasi jalur MEK / ERK (Ekstracellular Reactive Kinase). Temuan 
baru ini memberikan bukti untuk mendukung kemungkinan keterlibatan $\mathrm{AQP}_{3}$ pada dehidrasi kulit diinduksi UV. (19) Retinol adalah salah satu bahan yang paling umum digunakan dalam kosmetik antipenuaan kulit. Salah satu bahan aktif retinol adalah All trans retinoic acid (ATRA). Aplikasi topikal ATRA meningkatkan perbaikan kerusakan in vivo kulit akibat paparan sinar UV, yang mengarah ke pembentukan kerut. Studi menunjukkan bukti lain bahwa aplikasi topikal dari retinol atau ATRA memiliki efek yang signifikan mengurangi photoaging akibat induksi UV, yaitu kerut, kehilangan air, serta memperlambat penyembuhan luka. (20)

\section{Peningkatan ekspresi $A Q P_{3}$ setelah induksi ekstrak piptadenia colubrine}

Penggunaan zat aktif dari sumber-sumber alam khususnya tanaman, berpotensi efisien dalam mencegah gangguan fisiologis, terutama yang melibatkan estetika kulit. Di antara zatzat tersebut, polisakarida yang berasal dari beragam dan karakteristik struktural telah dipelajari sebagai pengubah respon biologis. Dalam studi ini, pohon polongan asli dari hutan hujan Amerika Selatan Piptadenia colubrina Bth. (botani sinonim Anadenanthera colubrina [Vell.] Brenan), dikenal sebagai Angico-branco, digunakan sebagai sumber polisakarida dan keterlibatannya dalam hidrasi kulit dan integritas telah diselidiki. Ekspresi gen untuk AQP3 diukur dengan real-time PCR, menggunakan model in vitro dari keratinosit manusia diinkubasi dengan ekstrak hydroglycolic P. colubrina (HEPC). Jumlah protein AQP3 juga dikonfirmasi oleh imunohistokimia dalam eksplan kulit manusia. Selain itu uji klinis dilakukan untuk mengevaluasi efek dari gel krim yang mengandung HEPC pada indeks gliserol dan kapasitansi kulit (indeks korneometri). (20) Ekspresi $\mathrm{AQP}_{3}$ dipelajari dengan pajanan kultur sel kulit dengan HEPC untuk periode waktu yang berbeda. Ekspresi mRNA $\mathrm{AQP}_{3}$ dideteksi dengan real-time PCR. Ekspresi meningkat setelah inkubasi selama 2 jam, memuncak pada 6 jam, dan menurun ke tingkat basal setelah 48 jam (data tidak ditampilkan). Setelah waktu pengobatan standar 6 jam, ekspresi $\mathrm{AQP}_{3}$ diukur dalam konsentrasi yang berbeda dari HEPC $(2,5,5,10$, dan $20 \mathrm{mg} / \mathrm{mL})$. Konsentrasi 10 dan $20 \mathrm{mg} / \mathrm{mL}$ memicu peningkatan signifikan dalam ekspresi $\mathrm{AQP}_{3}(\mathrm{P}<0,01)$. Untuk analisis imunohistokimia, biopsy lapisan kulit yang diperoleh dari pasien operasi bedah plastik dengan HEPC dalam konsentrasi $10 \mathrm{mg} / \mathrm{mL}$ selama 24 jam dan diinkubasi dengan antibodi poliklonal anti - $\mathrm{AQP}_{3}$ komersial. Visualisasi menunjukkan peningkatan ekspresi $\mathrm{AQP}_{3}$ dalam membran sel keratinosit dibandingkan dengan kelompok kontrol, yang bisa dikaitkan dalam tingkat tertentu, peningkatan transportasi $\mathrm{AQP}_{3}$ ke fraksi membran. (20)
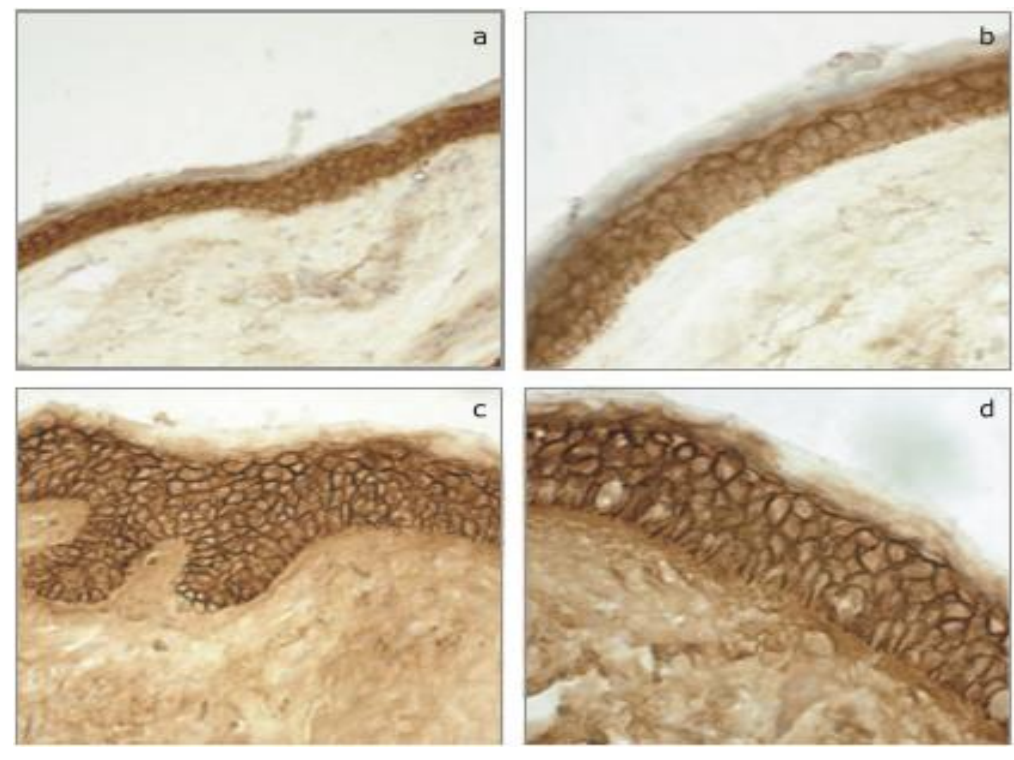
Gambar 6. Pengaruh HEPC (10 mg / mL) pada aquaporin-3 immunoreactivity dalam eksplan kulit manusia selama 24 jam. Bagian histologis immunostained oleh kelinci antiserum diarahkan terhadap $\mathrm{AQP}_{3}$ dalam diobati (a, c) dan diobati (b, d) eksplan (20 dan 40 x perbesaran).

E. Pengaruh Green Coffea Arabica L.seed oil pada komponen matriks ekstraseluler dan ekspresi $\mathrm{AQP}_{3}$ pada lapisan epidermis normal kulit manusia

Green Coffea arabica L.seed oil banyak digunakan dalam formulasi kosmetik, meskipun dampaknya pada sel-sel kulit manusia masih tidak jelas dan sebagian penelitian tidak dipublikasikan. Dalam penelitian ini, dievaluasi pengaruh efek in vitro green coffea Arabica L.seed (C. arabica L.) oil (GCO) pada sintesis kolagen, elastin, dan glikosaminoglikan (GAG) dan dalam perubahan growth faktor - betal (TGF-beta1) dan granulocyte macrophage colony stimulating factor (GM-CSF) oleh fibroblast kulit manusia dan juga meneliti kemampuan GCO untuk meningkatkan ekspresi mRNA aquaglycerolporins-3 $\left(\mathrm{AQP}_{3}\right)$ dalam kultur keratinosit dan kulit eksplan manusia. (21)

Fibroblas manusia diinkubasi selama 48 jam dengan beberapa konsentrasi GCO $(3.12,6.25$, 12.5 , 25.0 dan $50.0 \mathrm{mg} / \mathrm{mL}$ ). Untuk mengevaluasi ekspresi relative $\mathrm{AQP}_{3}$, menggunakan real-time polymerase chain reaction reverse transkripsi, keratinosit diinkubasi selama 3-6 jam dengan konsentrasi optimal GCO 25,0 mg/mL. Biopsi kulit juga diinkubasi dengan GCO $(25,0 \mathrm{mg} / \mathrm{mL})$ dan dilakukan immunostained oleh antiserum terhadap AQP 3 . (21)

Hasil penelitian menunjukkan bahwa inkubasi dengan GCO menghasilkan stimulasi tergantung dosis dalam sintesis kolagen, elastin, dan GAG, selain meningkatkan pelepasan faktor pertumbuhan TGF-beta1 dan GM-CSF. GCO juga menginduksi ekspresi mRNA $\mathrm{AQP}_{3}$, yang mencapai tingkat hingga 6,5 kali lipat lebih tinggi daripada kontrol. (21)

\section{F. Peran Ajurga Turkesnita pada Peningkatan Ekspresi $\mathrm{AQP}_{3}$}

Untuk mengetahui sintesis kolagen, elastin dan GAG fibroblast manusia diinkubasi selama 48 jam dengan beberapa konsentrasi GCO $(3.12 ; 6.25 ; 12.5 ; 25.0$; dan $50.0 \mathrm{mg} / \mathrm{mL})$. Untuk mengevaluasi ekspresi $\mathrm{AQP}_{3}$ relatif, menggunakan real-time reverse transcription $P C R$, keratinosit diinkubasi selama 3-6 jam dengan konsentrasi optimal GCO $25.0 \mathrm{mg} / \mathrm{mL}$. Biopsi kulit juga diinkubasi dengan GCO $(25.0 \mathrm{mg} / \mathrm{mL})$ dan dilakukan immunostained oleh antiserum terhadap $\mathrm{AQP}_{3}$. (21)

Hasil penelitian menunjukkan bahwa inkubasi fibroblast dengan GCO menghasilkan simulasi yang tergantung dosis dalam sintesis kolagen, elastin dan GAG. Selain meningkatkan pelepasan faktor pertumbuhan TGF-beta 1 dan GM-CSF. GCO juga menginduksi ekspresi mRNA $\mathrm{AQP}_{3}$, pada keratinosit yang mencapai tingkat ekspresi hingga 6.5 kali lipat lebih tinggi daripada kontrol negatif yang tidak diberi perlakuan. (21)

\section{KESIMPULAN DAN SARAN}

a. Pada penuaan kulit terjadi perubahan kadar kandungan air dalam lapisan epidermis dan fungsi barrier kulit sehingga timbul xerosis kutis, deskuamasi, meningkatnya kerapuhan kulit dan tertundanya penyembuhan luka.

b. $\mathrm{AQP}_{3}$ adalah protein utama yang berperan pada hidrasi kulit, pada keratinosit $\mathrm{AQP}_{3}$ mempengaruhi hidrasi kulit melalui transportasi air dan gliserol yang berperan pada proses proliferasi dan diferensiasi keratinosit.

c. Aktivasi $\mathrm{AQP}_{3}$ oleh obat topikal bermanfaat dalam penyembuhan luka dan pengobatan penuaan dini, sehingga $\mathrm{AQP}_{3}$ tampaknya menjadi protein kunci sebagai target untuk pengobatan di masa depan untuk mengatur hidrasi kulit terutama pada kulit kering. 


\section{REFERENSI}

${ }^{1}$ Verdier - Sevrain S, Bonte F. Skin hydration: a review on its molecular mechanism. J CosmetDermatol. 2007; 675 - 82 .

${ }^{2}$ Verkman AS. Aquaporins at a glance. J Cell Sci. 2011; 124 (pt 13); 2107 - 2112.

${ }^{3}$ Jamot MB, Sougrat R, Tailhardat M et al. Expression and function of aquaporins in human skin is aquaporin-3 just a glycerol transporter. BiochemBiophysActa. 2006; 1758: $1034-42$.

${ }^{4}$ Sougrat R, Morand M, Gondran $\mathrm{C}$, et al. Functional expression of $\mathrm{AQP}_{3}$ in human skin epidermis and reconstructed epidermis. J Invest Dermatol. 2002; 118: 678 - 685 .

${ }^{5}$ Jamot MB, Daraspe J, Bonte F, et al. Skin aquaporins: function in hydration, would healing, and skin epidermis homeostasis. HandbExpPharmacol. 2009; (190): 205-217.

${ }^{6} \mathrm{Ma} \mathrm{T}$, Hara M, Sougrat R et al. Impaired stratum corneum hydration in mice lacking epidermal water channel aquaporin-3. The J of Biological Chemistry. 2002; 277: 17147 - 17153.

${ }^{7}$ Hara - Chikuma M, Verkman AS. Roles of aquaporin-3 in epidermis. J Invest Dermatol. 2008; 128: 2145-2151.

${ }^{8}$ Hara M, Verkman AS. Aquaporin-3 functions as a glycerol transporter in mammalian skin. Biol Cell. 2005; 97: 479-486.

${ }^{9}$ Wang F, Feng X-C, Li YM et al. Aquaporin as potential drug targets. Acta Pharmacologica Sinica. 2006; 27 (4): 395-401.

${ }^{10}$ Nakahigashi K, Kabashima K, Ikoma A et al. Upregulation of Aquaporin-3 Is Involved in Keratinocyte Proliferation and Epidermal Hyperplasia. Journal of Invest Dermatol. 2011; 131: 865-73.

${ }^{11} \mathrm{Li}$ J, Tang $\mathrm{H}, \mathrm{Hu} \mathrm{X}$ et al. Aquaporin-3 gene and protein expression in sun-protected human skin decreases with skin ageing. Austr J Dermatol. 2010; 51: 106 - 112.

${ }^{12} \mathrm{Cao} \mathrm{C}$, Sun Y, Healey S et al. EGFR mediated expression of aquaporin-3 is involved in human skin fibroblast migration. Biochem J. 2006; 400: 225-234.

${ }^{13} \mathrm{Ma} \mathrm{T}$, Hara M, Sougrat $\mathrm{R}$ et al. Membrane transport structure function and biogenesis: Impaired stratum corneum hydration in mice lacking epidermal water channel aquaporin-3. J Biol Chem. 2002, 277: 17147-17153.

${ }^{14}$ Mirza R, Hayasaka S, Kambe F et al. Increased expression of aquaporin-3 in the epidermis of DHCR 24 knockout mice. Br J of Dermatol 2008; 158: 679-684.

${ }^{15}$ Garcia N Gondran C, Merion G et al. Impact of AQP3 inducer treatment on cultured human keratinocytes ex vivo human skin and volunteers. Int J CosmetSci. 2011; 33: 432 - 42.

${ }^{16}$ Bellernere G, Von Steften O, Oddus T. Retinoid acid increase aquaporin 3 expression in normal human skin. J Invest Dermatol. 128; 542-8.

${ }^{17}$ Hara M, Verkman AS. Aquaporin-3 facilitates epidermal call migration and proliferation during wound healing. J Mol Med. 2008; 86: $221-231$.

${ }^{18}$ Bovoy - Jamot M, Darasp J, Bonte F et all. Skin aquaporins ; function in hydration, wound hialing, and skin epidermis homeostasis. 205-2017.

${ }^{19}$ Cao C, Wan S, Jiang Q et al. All-trans retinoic and attenuates ultraviolet radiation induced down regulation of aquaporin 5 and water permeability. J Cell Physiol. 2008 ; 215 : 506-16.

${ }^{20}$ Pereda $\mathrm{M}$ del C, Dieamant $\mathrm{G}$ dec, Eberlin S et al. Expression of differential genes involved in the maintenance of water balance in human skin by Piptadenia colubrine extract. $\mathrm{J}$ CosmDermatol. 2010; 9: $35-43$.

${ }^{21}$ Pereda Md IC, Dieamant G de B, E berlin S rt al. Effect of green Coffea Arabica L.seed oil on extracellular matrix components and water - channel expression in in vitro and ex vivo human skin model. J CosmDermatol. 2009; 8: 56 - 62. 